\title{
Respon Sawi pada Berbagai Konsentrasi dan Waktu Pemberian Ekstrak Air Kulit Buah Jengkol Segar
}

\author{
Response of Mustard to Various Concentrations and Time of Application of \\ Jiringa-Pericarp Water Extract \\ Putriany Simanjuntak, Uswatun Nurjanah*, Edhi Turmudi \\ Program Studi Agroekoteknologi, Fakultas Pertanian, Universitas Bengkulu \\ *: uswatun.nurjannah@gmail.com
}

\begin{abstract}
The aim of this study was to evaluate the response of mustard to various concentrations of jiringa-pericarp water extract applied before or at planting. The study was conducted in November 2015-January 2016 located in a greenhouse using Completely Randomized Design, 2 factors and 4 replications. The first factor, concentration of jiringa-pericarp water extract consisted of 6 treatments: $165 \mathrm{~g} / \mathrm{L}, 330$ $\mathrm{g} / \mathrm{L}, 495 \mathrm{~g} / \mathrm{L}, 660 \mathrm{~g} / \mathrm{L}, 825 \mathrm{~g} / \mathrm{L}$ and $990 \mathrm{~g} / \mathrm{L}$ and as comparison were 4 control plants. The second factor consisted of application one week before planting and at the time of planting. Each experimental unit consisted of two plants. The results showed that the application jiringa extract at palnting time with the concentration of $825 \mathrm{~g} / \mathrm{L}$ resulted in the lowest leaf area and root fresh weight. The percentage of mustard growth inhibition respectively were $51.54 \%$ and $56.69 \%$ when compared to the control. Jiringa water extract applied at planting time inhibited mustard growth more significant when compared to that 1 week before planting. The lowest average values for variables of leaf number, fresh weight and crown dry weight were obtained at $825 \mathrm{~g} / \mathrm{L}$ concentration with a percentage of obstacles of $35.57 \% ; 47.16 \%$ and $40.70 \%$ when compared with controls.
\end{abstract}

Keywords: jiringa-pericarp water extract, concentration, growth, yield, mustard, time of application

\begin{abstract}
ABSTRAK
Penelitian bertujuan untuk menjelaskan respon sawi pada berbagai konsentrasi ekstrak air kulit buah jengkol yang diaplikasikan sebelum dan saat tanam. Penelitian telah dilaksanakan bulan November 2015-Januari 2016. Penelitian dilakukan di rumah kaca dengan menggunakan Rancangan Acak Lengkap (RAL) 2 faktor dan 4 ulangan. Faktor pertama konsentrasi ekstrak air kulit buah jengkol segar terdiri dari 6 perlakuan: $165 \mathrm{~g} / \mathrm{L}\left(\mathrm{A}_{1}\right), 330 \mathrm{~g} / \mathrm{L}\left(\mathrm{A}_{2}\right), 495 \mathrm{~g} / \mathrm{L}\left(\mathrm{A}_{3}\right), 660 \mathrm{~g} / \mathrm{L}\left(\mathrm{A}_{4}\right), 825 \mathrm{~g} / \mathrm{L}\left(\mathrm{A}_{5}\right)$ dan $990 \mathrm{~g} / \mathrm{L}\left(\mathrm{A}_{6}\right)$ dan sebagai pembanding adalah kontrol $\left(\mathrm{A}_{0}\right)$. Faktor kedua waktu pemberian: satu minggu sebelum tanam dan saat tanam. Sehingga diperoleh 48 unit percobaan ditambah 4 unit kontrol. Masing-masing unit percobaan terdiri dari dua tanaman. Hasil penelitian menunjukkan bahwa aplikasi ekstrak air kulit buah jengkol segar pada saat tanam dengan konsentrasi $825 \mathrm{~g} / \mathrm{L}$ menghasilkan luas daun dan bobot basah akar paling rendah. Persentase hambatan yang dihasilkan berturut-turut sebesar $51.54 \%$ dan $56.69 \%$ bila dibandingkan dengan kontrol. Ekstrak air kulit buah jengkol segar yang diaplikasikan pada saat tanam lebih menghambat bila dibandingkan dengan 1 minggu sebelum tanam pada pertumbuhan tanaman sawi pindah tanam umur 4 minggu. Nilai rata - rata terendah untuk variabel jumlah daun, bobot segar dan bobot kering tajuk diperoleh pada pemberian konsentrasi $825 \mathrm{~g} / \mathrm{L}$ dengan persentase hambatan sebesar $35.57 \% ; 47.16 \%$ dan $40.70 \%$ bila dibandingkan dengan kontrol.
\end{abstract}

Kata kunci: Ekstrak air kulit buah jengkol segar, konsentrasi, pertumbuhan dan hasil sawi, waktu aplikasi 


\section{PENDAHULUAN}

Sawi merupakan tanaman sayuran semusim yang banyak dibudidayakan petani karena dapat tumbuh pada ketinggian tempat 5-1 $200 \mathrm{~m}$ di atas permukaan laut. Tanaman ini mempunyai sistem perakaran tunggang dengan kedalaman 0-30 cm. Distribusi akar yang dangkal menyebabkan akar sawi rentan terhadap gangguan biotik maupun abiotik yang ada di permukaan tanah. Salah satu gangguan abiotik adalah senyawa racun (alelopat) yang dikeluarkan oleh tumbuhan, misalnya kulit jengkol.

Kulit jengkol mengandung alkaloid, terpenoid, saponin dan asam fenolat. Asam fenolat ini di dalamnya termasuk flavonoid dan tanin (Susanti, 2010). Senyawa fenol mempengaruhi beberapa proses penting seperti, penyerapan mineral, keseimbangan air, respirasi, fotosintesis, sintesis protein, klorofil dan fitohormon. Kandungan flavonoid dan tanin dalam ekstrak kulit buah jengkol dapat merusak struktur membran sel sehingga permeabilitasnya akan menurun (Masriadi, 2014).

Hasil penelitian sebelumnya menunjukkan bahwa pemanfaatan ekstrak kulit buah jengkol segar yang diaplikasikan dengan konsentrasi tinggi dapat menghambat perkecambahan biji gulma berdaun lebar dan biji tanaman sawi. Nurjannah (2013) menyatakan aplikasi kulit buah jengkol segar dapat menggantikan penyiangan gulma pada 21 dan 42 hari setelah tanam pada tanaman padi dan hasil terbaik diperoleh dengan takaran 15 ton/ha. Penekanan alelopat terhadap gulma daun lebar lebih besar bila dibandingkan dengan rumputan dan tekian pada umur 3 minggu setelah tanam. Oleh karena itu perlu dilakukan pengujian hambatan alelokimia dari ekstrak kulit buah jengkol segar terhadap pertumbuhan sawi, dikarenakan tanaman sawi banyak dimanfaatkan, mudah dicari, juga memiliki sifat yang responsif terhadap bahan alelokimia.

Toksisitas alelokimia dalam ling- kungan merupakan fungsi dari konsentrasi, laju perubahan, umur dan tahap fisiologi tanaman, iklim, musim dan kondisi lingkungan. Konsentrasi 5\% (w/v) dapat mengurangi kandungan air sebesar $20 \%$, potensial osmotik $50 \%$, transpirasi turun $75 \%$ yang diikuti kenaikan resistensi difusi sebesar 75\% dan laju fotosintesis sebesar $74 \%$, kandungan ABA naik sebesar $1000 \%$ dan kerusakan membran sebesar $130 \%$ bila dibandingkan dengan kontrol.

Eni (2010) mengatakan bahwa aplikasi kulit buah jengkol setelah tanam lebih efektif dalam menekan pertumbuhan gulma berdaun lebar dibandingkan dengan aplikasi saat tanam dan sebelum tanam. Sedangkan Nurjannah (2013) mengatakan bahwa aplikasi pemberian ektrak kulit buah jengkol saat tanam akan lebih efektif untuk menghambat pertumbuhan gulma daun lebar dibandingkan aplikasi sebelum tanam.

Berdasarkan penelitian sebelumnya mengenai penggunaan kulit buah jengkol sebagai herbisida dan kemampuannya menghambat viabilitas biji gulma, serta berdasarkan analisis kandungan hara dari kulit buah jengkol segar, maka perlu dilakukan penelitian tentang penggunaan ekstrak kulit buah jengkol pada hambatan pertumbuhan sawi. Penelitian ini dilakukan guna memperoleh informasi mengenai konsentrasi dan waktu yang tepat penggunaan kulit buah jengkol yang akan dijadikan sebagai bahan alami pembuatan bioherbisida pra dan purna tumbuh.

Tujuan penelitian ini menjelaskan respon pertumbuhan dan hasil tanaman sawi pada berbagai konsentrasi kulit buah jengkol yang diaplikasikan sebelum dan saat tanam.

\section{METODE PENELITIAN}

Penelitian ini dilakukan pada bulan November 2015 - Januari 2016 di rumah 
kaca Laboratorium Agronomi, Fakultas Pertanian UNIB. Penelitian menggunakan Rancangan Acak Lengkap (RAL) dengan dua faktor dan empat ulangan. Faktor pertama adalah konsentrasi ekstrak air kulit buah jengkol segar yang terdiri dari 6 perlakuan yaitu; $165 \mathrm{~g} / \mathrm{L}\left(\mathrm{A}_{1}\right), 330 \mathrm{~g} / \mathrm{L}\left(\mathrm{A}_{2}\right)$, $495 \mathrm{~g} / \mathrm{L}\left(\mathrm{A}_{3}\right), 660 \mathrm{~g} / \mathrm{L}\left(\mathrm{A}_{4}\right), 825 \mathrm{~g} / \mathrm{L}\left(\mathrm{A}_{5}\right)$ dan $990 \mathrm{~g} / \mathrm{L}\left(\mathrm{A}_{6}\right)$; sebagai pembanding adalah kontrol $\left(\mathrm{A}_{0}\right.$, air). Faktor kedua adalah waktu pemberian yaitu 1 minggu sebelum tanam $\left(\mathrm{B}_{1}\right)$ dan saat tanam $\left(\mathrm{B}_{2}\right)$. Dari kedua faktor tersebut diperoleh 12 kombinasi perlakuan, setiap perlakuan diulang empat) kali sehingga diperoleh 48 unit percobaan ditambah dengan 4 unit sebagai kontrol. Masing-masing unit percobaan terdiri dari 2 tanaman sehingga secara keseluruhan terdapat 104 pot.

Benih yang digunakan untuk penelitian terlebih dahulu disemai pada media tanam berupa campuran tanah, pupuk kandang dan pasir dengan perbandingan $1: 1: 1$. Campuran media tanam tersebut dimasukkan ke dalam nampan ukuran 35 $\mathrm{cm}$ x $50 \mathrm{~cm}$. Persemaian dilakukan dengan cara menebarkan benih sawi secara beralur pada media yang telah dilembabkan terlebih dahulu dengan air. Lama persemaian 1 minggu (tanaman berdaun 2-3 helai). Kemudian tanaman yang sudah berdaun 2-3 helai dibibitkan ke dalam cup $150 \mathrm{ml}$ yang sudah diisi dengan media tanam. Lama pembibitan 3 minggu.

Ekstrak kulit buah jengkol segar dibuat dengan memotong kulit buah jengkol menjadi potongan sebesar $1 / 2 \mathrm{~cm}$ dan ditimbang sesuai dengan kebutuhan perlakuan. Selanjutnya potongan tersebut direndam dengan air selama 24 jam (Nie, 2007; Sodaeizaedah et al., 2009). Larutan terbentuk disaring dengan menggunakan kain dan air yang tertinggal diaplikasikan pada media tanam sesuai dengan perlakuan.

Tanah yang digunakan dalam percobaan ini adalah lapisan atas (top soil) yang diambil dari Kebun Percobaan Fakultas Pertanian UNIB. Setiap ember diisi sebanyak $4 \mathrm{~kg}$ tanah. Setelah itu ember disusun di dalam rumah plastik dengan jarak antar ember $30 \mathrm{~cm}$. Ember yang telah diisi dengan tanah disiram dengan ekstrak air kulit buah jengkol sesuai dengan perlakuan. Bibit sawi ditanam sebanyak 1 bibit per ember.

Pemeliharaan tanaman sawi meliputi penyiraman, penyiangan dan pengendalian hama. Penyiraman dilakukan sebanyak dua kali dalam sehari yaitu pagi dan sore hari. Penyiangan dilakukan secara manual dengan cara mencabut gulma. Pengendalian hama dilakukan dengan cara menangkap hama dan membunuhnya.

Pemanenan dilakukan setelah sawi berumur 8 MST. Kriteria panen sawi ketika daun paling bawah menunjukkan warna kuning dan belum berbunga (Fery, 2013). Pengamatan dilakukan terhadap variabel: Jumlah daun, luas daun $\left(\mathrm{cm}^{2}\right)$ yang diukur secara Grafimetri, bobot segar tajuk dan akar (g), bobot kering tajuk dan akar (g) ditimbang setelah terlebih dahulu dioven pada suhu $70^{\circ} \mathrm{C}$ selama 48 jam atau sampai bobot sudah mencapai konstan. Penimbangan dilakukan dengan menggunakan timbangan digital.

Data hasil pengamatan dianalisis dengan uji $\mathrm{F}$ pada taraf 5\%. Data yang berpengaruh nyata dan ada interaksi maka dilanjutkan dengan uji lanjut DMRT pada taraf 5\%. Sedangkan jika terdapat pengaruh nyata pada konsentrasi yang berbeda maka dilanjutkan dengan Uji Polinomial Ortogonal.

\section{HASIL DAN PEMBAHASAN}

Pertumbuhan adalah suatu pertambahan dalam ukuran yang bersifat irreversible, karena bersifat multisel maka pertumbuhan bukan saja dalam volume tetapi 
juga pertambahan dalam hal bobot, jumlah sel, dan banyaknya protoplasma. Hasil analisis varian terhadap semua variabel pengamatan disajikan pada Tabel 1 .

Tabel 1. menunjukkan terjadi interaksi antar perlakuan terhadap variabel luas daun, bobot basah dan bobot kering akar tanaman. Perlakuan perbedaan konsentrasi berpengaruh tidak nyata terhadap variabel yang diamati, sedangkan perbedaan waktu pemberian ekstrak kulit buah jengkol segar berpengaruh sangat nyata terhadap jumlah daun serta berpengaruh nyata pada bobot basah akar tanaman dan bobot kering akar.

Tabel 2 menunjukkan pengaplikasian ekstrak kulit buah jengkol segar menghambat pertumbuhan dari tanaman sawi. Hal ini dibuktikan dengan perlakuan yang tidak diberikan ekstrak kulit buah jengkol segar (kontrol, $\mathrm{A}_{0}$ ) menghasilkan luas daun, bobot segar dan bobot kering akar tanaman lebih tinggi bila dibandingkan dengan yang diaplikasikan ekstrak kulit buah jengkol segar. Kulit buah jengkol mengandung senyawa fenolat yang meracuni tanaman sehingga dapat menghambat pertumbuhan dan perkembangannya. Menurut Susanti (2010) kulit jengkol mengandung alkaloid, terpenoid, saponin dan asam fenolat. Senyawa fenol mengandung tanin dan flavonoid sehingga mempengaruhi beberapa proses penting seperti, penyerapan mineral, keseimbangan air, respirasi, fotosintesis, sintesis protein, klorofil dan fitihormon (Einheling, 1995). Hal yang sama ditambahkan oleh Masriadi (2014) yang menyatakan bahwa kandungan flavonoid dan tanin dalam ekstrak kulit buah jengkol juga dapat merusak struktur membran sel sehingga permeabilitasnya akan menurun.

Pengaplikasian ekstrak kulit buah jengkol segar pada saat tanam dengan konsentrasi $825 \mathrm{~g} / \mathrm{L}$ menghasilkan luas daun dan bobot basah akar tanaman paling rendah $\left(1225.61 \mathrm{~cm}^{2}\right.$ dan $\left.9.86 \mathrm{~g}\right)$ dan berbeda nyata dengan konsentrasi $330 \mathrm{~g} / \mathrm{L}$.
Hambatan yang dihasilkan berturut-turut sebesar $51.54 \%$ dan $56.69 \%$ bila dibandingkan dengan kontrol. Bobot kering akar tanaman paling rendah $(0.81 \mathrm{~g})$ dihasilkan pada konsentrasi $495 \mathrm{~g} / \mathrm{L}$ yang diaplikasikan saat tanam. Hal ini disebabkan aplikasi pada saat tanam menyebabkan akar langsung kontak dengan alelopat dan semakin tinggi konsentrasi maka kandungan senyawa penghambat juga semakin tinggi sehingga tanaman semakin teracuni. Hasil penelitian Zuhri et al. (2010) membuktikan bahwa pada pemberian ekstrak kulit jengkol konsentrasi 40\% merupakan dosis yang toksik apabila dibandingkan dengan konsentrasi $10 \%$, 20\%, dan 30\% sehingga kecambah padi tidak mampu muncul ke permukaan tanah. Nurjannah et al. (2015) mengatakan semakin tinggi kadar ekstrak kulit buah jengkol maka akar kecambah gulma lakum air akan semakin pendek. Ini disebabkan dengan meningkatnya kadar ekstrak kulit buah jengkol maka terjadi peningkatan ketersediaan zat-zat alelopat, sehingga memperbesar respon penghambatan. Meningkatnya konsentrasi alelopat akan diikuti dengan meningkatnya zat - zat alelopat yang terkandung sehingga akan memperbesar daya hambatnya (Donly et al., 2009).

Berdasarkan sidik ragam perlakuan dengan taraf konsentrasi ekstrak kulit buah jengkol segar berbeda tidak nyata sedangkan waktu aplikasi dari ekstrak kulit buah jengkol segar berbeda nyata antara pengaplikasian 1 minggu sebelum tanam dan saat tanam pada variabel jumlah daun. Pada variabel tingkat kehijauan daun dan bobot kering tajuk berbeda tidak nyata pada taraf konsentrasi dan waktu aplikasi ekstrak kulit buah jengkol segar. Hasil analisis uji lanjut pada setiap variabel menggunakan Duncan multiple range test (DMRT) pada taraf beda nyata $5 \%$ disajikan pada Tabel 3 .

Tabel 3 menunjukkan bahwa pengaplikasian ekstrak kulit buah jengkol segar 
Tabel 1. Rangkuman nilai analisis varian untuk variabel pertumbuhan dan hasil sawi

\begin{tabular}{llccc}
\hline No. & \multicolumn{1}{c}{ Variabel yang diamati } & Konsentrasi & $\begin{array}{c}\text { F-hitung } \\
\text { Waktu Aplikasi }\end{array}$ & Interaksi \\
\hline 1. & Jumlah Daun & $1.246^{\mathrm{ns}}$ & $8.456^{* *}$ & $2.340^{\mathrm{ns}}$ \\
2. & Luas Daun & $1.783^{\mathrm{ns}}$ & $3.317^{\mathrm{ns}}$ & $2.989^{*}$ \\
3. & Kehijauan daun & $2.272^{\mathrm{ns}}$ & $1.843^{\mathrm{ns}}$ & $0.419^{\mathrm{ns}}$ \\
4. & Bobot Segar Tajuk & $1.329^{\mathrm{ns}}$ & $3.506^{\mathrm{ns}}$ & $1.973^{\mathrm{ns}}$ \\
5. & Bobot segar Akar Tanaman & $1.643^{\mathrm{ns}}$ & $5.499^{*}$ & $2.989^{*}$ \\
6. & Bobot Kering Tajuk & $1.349^{\mathrm{ns}}$ & $2.226^{\mathrm{ns}}$ & $1.017^{\mathrm{ns}}$ \\
7. & Bobot Kering Akar Tanaman & $0.958^{\mathrm{ns}}$ & $5.609^{*}$ & $3.429^{*}$ \\
\hline
\end{tabular}

Keterangan: ${ }^{*}=$ berpengaruh nyata, ${ }^{* *}=$ Sangat Berpengaruh nyata, $\mathrm{ns}=$ Tidak berpengaruh nyata

Tabel 2. Rata-rata luas daun, bobot basah dan bobot kering akar tanaman pada interaksi antara konsentrasi alelopat dan perbedaan waktu aplikasi kulit buah jengkol segar

\begin{tabular}{|c|c|c|c|c|c|c|}
\hline \multirow[b]{2}{*}{ Waktu } & \multicolumn{6}{|c|}{ Konsentrasi } \\
\hline & $\begin{array}{c}165 \mathrm{~g} / \mathrm{L} \\
(\mathrm{A} 1)\end{array}$ & $\begin{array}{c}330 \mathrm{~g} / \mathrm{L} \\
(\mathrm{A} 2)\end{array}$ & $\begin{array}{c}495 \mathrm{~g} / \mathrm{L} \\
\text { (A3) }\end{array}$ & $\begin{array}{c}660 \mathrm{~g} / \mathrm{L} \\
(\mathrm{A} 4)\end{array}$ & $\begin{array}{c}825 \mathrm{~g} / \mathrm{L} \\
(\mathrm{A} 5)\end{array}$ & $\begin{array}{c}990 \mathrm{~g} / \mathrm{L} \\
(\mathrm{A} 6)\end{array}$ \\
\hline \multicolumn{7}{|c|}{ Luas Daun $\left(\mathrm{cm}^{2}\right)$} \\
\hline $1 \mathrm{MST}$ (B1) & $\begin{array}{c}2351.25 \mathrm{ABC} \\
\mathrm{a}\end{array}$ & $\begin{array}{c}1170.64 \mathrm{D} \\
\mathrm{b}\end{array}$ & $\begin{array}{c}2744.68 \mathrm{AB} \\
\mathrm{a}\end{array}$ & $\begin{array}{c}2061.3 \mathrm{BC} \\
\mathrm{b}\end{array}$ & $\begin{array}{c}1689.75 \mathrm{CD} \\
\mathrm{a}\end{array}$ & $\begin{array}{c}2754.69 \mathrm{~A} \\
\mathrm{a}\end{array}$ \\
\hline $\begin{array}{l}\text { Saat Tanam } \\
\text { (B2) }\end{array}$ & $\begin{array}{c}1755.96 \mathrm{ABC} \\
\mathrm{b}\end{array}$ & $\begin{array}{c}2197.61 \mathrm{~A} \\
\mathrm{a}\end{array}$ & $\begin{array}{c}1379.89 \mathrm{BC} \\
\mathrm{b}\end{array}$ & $\begin{array}{c}2155.82 \mathrm{~A} \\
\mathrm{a}\end{array}$ & $\begin{array}{c}1225.61 \mathrm{C} \\
\mathrm{b}\end{array}$ & $\begin{array}{c}1920.21 \mathrm{AB} \\
\mathrm{b}\end{array}$ \\
\hline Kontrol (A0) & 2529.321 & & & & & \\
\hline \multicolumn{7}{|c|}{ Bobot Basah Akar Tanaman (g) } \\
\hline $1 \mathrm{MST}(\mathrm{B} 1)$ & $\begin{array}{c}23.48 \mathrm{BC} \\
\mathrm{a}\end{array}$ & $\begin{array}{c}10.37 \mathrm{D} \\
\mathrm{b}\end{array}$ & $\begin{array}{c}26.78 \mathrm{AB} \\
\mathrm{a}\end{array}$ & $\begin{array}{c}18.03 \mathrm{BCD} \\
\mathrm{a}\end{array}$ & $\begin{array}{c}14.76 \mathrm{CD} \\
\mathrm{A}\end{array}$ & $\begin{array}{c}33.52 \mathrm{~A} \\
\mathrm{a}\end{array}$ \\
\hline $\begin{array}{l}\text { Saat Tanam } \\
\text { (B2) }\end{array}$ & $\begin{array}{c}14.95 \mathrm{AB} \\
\mathrm{b}\end{array}$ & $\begin{array}{c}23.7 \mathrm{~A} \\
\mathrm{a}\end{array}$ & $\begin{array}{c}12.9 \mathrm{~B} \\
\mathrm{~b}\end{array}$ & $\begin{array}{c}14.00 \mathrm{~B} \\
\mathrm{~b}\end{array}$ & $\begin{array}{c}9.86 \mathrm{~B} \\
\mathrm{~b}\end{array}$ & $\begin{array}{c}15.18 \mathrm{AB} \\
\mathrm{b}\end{array}$ \\
\hline Kontrol (A0) & 22.775 & & & & & \\
\hline \multicolumn{7}{|c|}{ Bobot kering akar tanaman (g) } \\
\hline 1 MST (B1) & $\begin{array}{c}3.05 \mathrm{BC} \\
\mathrm{a}\end{array}$ & $\begin{array}{c}1.69 \mathrm{C} \\
\mathrm{b}\end{array}$ & $\begin{array}{c}4.08 \mathrm{AB} \\
\mathrm{a}\end{array}$ & $\begin{array}{c}2.48 \mathrm{BC} \\
\mathrm{a}\end{array}$ & $\begin{array}{c}2.1 \mathrm{C} \\
\mathrm{a}\end{array}$ & $\begin{array}{c}5.71 \mathrm{~A} \\
\mathrm{a}\end{array}$ \\
\hline $\begin{array}{l}\text { Saat Tanam } \\
\text { (B2) }\end{array}$ & $\begin{array}{c}2.22 \mathrm{AB} \\
\mathrm{b}\end{array}$ & $\begin{array}{c}3.72 \mathrm{~A} \\
\mathrm{a}\end{array}$ & $\begin{array}{c}0.81 \mathrm{C} \\
\mathrm{b}\end{array}$ & $\begin{array}{c}2.02 \mathrm{ABC} \\
\mathrm{b}\end{array}$ & $\begin{array}{c}1.78 \mathrm{BC} \\
\mathrm{b}\end{array}$ & $\begin{array}{c}1.61 \mathrm{BC} \\
\mathrm{b}\end{array}$ \\
\hline
\end{tabular}

Kotrol (A0) $\quad 3.6875$

Keterangan : Angka - angka yang diikuti huruf kecil yang sama pada baris yang sama dan huruf besar yang sama pada kolom yang sama menunjukkan berbeda tidak nyata menurut Uji Jarak Berganda Duncan pada taraf nyata $5 \%$; MST $=$ Minggu Sebelum Tanam

menghambat pertumbuhan tanaman sawi. Hal ini dibuktikan dengan perlakuan yang tidak diaplikasi ekstrak kulit buah jengkol segar (kontrol, A0) menghasilkan jumlah daun, tingkat kehijauan daun dan bobot kering tajuk lebih tinggi bila dibandingkan dengan yang diaplikasi ekstrak kulit buah jengkol segar. Persentase hambatan berturut-turut sebesar $35.57 \%$ dan $40.70 \%$ bila dibandingkan dengan kontrol pada variabel pengamatan jumlah daun dan bobot kering tajuk.

Perhitungan jumlah daun bertujuan untuk mengetahui pengaruh pelakuan terhadap kecepatan pertumbuhan tanaman yang ditandai dengan penambahan jumlah daun. Untuk memperoleh laju pertumbuhan yang maksimum, harus terdapat cukup banyak daun dalam tajuk untuk menyerap sebagian besar cahaya matahari yang jatuh ke atas tanaman. Jumlah daun mengindika- 
Tabel 3. Pengaruh taraf konsentrasi dan waktu aplikasi kulit buah jengkol segar terhadap jumlah daun dan bobot kering tajuk.

\begin{tabular}{lcc}
\hline Perlakuan & $\begin{array}{c}\text { Jumlah daun } \\
\text { (helai) }\end{array}$ & Bobot kering tajuk $(\mathrm{g})$ \\
\hline Konsentrasi (A) & 7.75 & 7.40 \\
$165 \mathrm{~g} / \mathrm{L}$ & 7.84 & 7.31 \\
$330 \mathrm{~g} / \mathrm{L}$ & 7.72 & 7.75 \\
$495 \mathrm{~g} / \mathrm{L}$ & 8.34 & 13.23 \\
$660 \mathrm{~g} / \mathrm{L}$ & 7.09 & 6.06 \\
$825 \mathrm{~g} / \mathrm{L}$ & 8.47 & 9.08 \\
$990 \mathrm{~g} / \mathrm{L}$ & & $9.79^{\mathrm{a}}$ \\
Waktu Aplikasi (B) & $8.39 \mathrm{a}$ & $7.15^{\mathrm{b}}$ \\
$1 \mathrm{mst}(\mathrm{B} 1)$ & $7.34 \mathrm{~b}$ & 9.275 \\
Saat Tanam (B2) & 9.3125 & \\
Kontrol (A0) & & \\
Ket : Angka yang diikuti huruf yang sama pada kolom dan baris yang sama berbeda tidak nyata pada uji \\
$\quad$ lanjut DMRT 5 \%, mst : minggu sebelum tanam.
\end{tabular}

Tabel 4. Rata-rata bobot basah tajuk pada taraf konsentrasi dan perbedaan waktu aplikasi kulit buah jengkol segar

\begin{tabular}{cc}
\hline Perlakuan & Bobot basah tajuk $(\mathrm{g})$ \\
\hline A1B1 & 167.93 \\
A1B2 & 125.81 \\
A2B1 & 92.90 \\
A2B2 & 152.27 \\
A3B1 & 180.96 \\
A3B2 & 99.38 \\
A4B1 & 152.62 \\
A4B2 & 146.02 \\
A5B1 & 123.78 \\
A5B2 & 90.61 \\
A6B1 & 190.36 \\
A6B2 & 135.02 \\
Kontrol & 171.47 \\
\hline Keterangan $:$ A0 $=$ Tanpa Ekstrak Jengkol (Kontrol), A1 = Konsentrasi $165 \mathrm{~g} / \mathrm{L}, \mathrm{A} 2=$ Konsentrasi 330 \\
Konsentrasi $990 \mathrm{~g} / \mathrm{L}, \mathrm{B} 1=1$ minggu sebelum tanam, $\mathrm{g} / \mathrm{L} 2=\mathrm{A} 5=$ saat tanam.
\end{tabular}

sikan banyaknya proses fotosintesis yang dilakukan oleh tanaman. Fotosintesis yang dihasilkan akan mempengaruhi pertumbuhan dan produksi dari tanaman tersebut (Dedi \& Verio, 2015).

Hasil sidik ragam perlakuan konsentrasi dan waktu aplikasi dari ekstrak kulit buah jengkol segar berbeda tidak nyata yaitu pada variabel bobot basah tajuk. Kon- sentrasi ekstrak kulit buah jengkol segar $825 \mathrm{~g} / \mathrm{L}$ yang diaplikasikan pada saat tanam menghasilkan bobot basah tajuk paling rendah $(90.61 \mathrm{~g})$ dengan persentase hambatan $47.16 \%$. Hal ini dikarenakan di dalam kulit buah jengkol terdapat senyawa fenolat yang meracuni tanaman sehingga dapat menghambat pertumbuhan dan perkembangannya. 


\section{KESIMPULAN DAN SARAN}

Perbedaan konsentrasi dan waktu aplikasi ekstrak kulit buah jengkol segar memberikan respon yang berbeda terhadap pertumbuhan tanaman sawi. Aplikasi ekstrak kulit buah jengkol segar pada saat tanam dengan konsentrasi $825 \mathrm{~g} / \mathrm{L}$ menghasilkan luas daun dan bobot basah akar paling rendah. Persentase hambatan yang dihasilkan berturut - turut sebesar 51.54 $\%$ dan $56.69 \%$ bila dibandingkan dengan kontrol. Ekstrak kulit buah jengkol segar yang diaplikasikan pada saat tanam lebih menghambat bila dibandingkan dengan 1 minggu sebelum tanam pada pertumbuhan tanaman sawi pindah tanam umur 4 minggu. Nilai rata-rata terendah untuk variabel jumlah daun, bobot segar dan bobot kering tanaman bagian atas diperoleh pada pemberian konsentrasi $825 \mathrm{~g} / \mathrm{L}$ dari ekstrak kulit buah jengkol segar. Persentase hambatan pada variabel berturut-turut $35.57 \%$, $47.16 \%$ dan $40.70 \%$ bila dibandingkan dengan kontrol.

\section{DAFTAR PUSTAKA}

Dedi, W. dan A. P. Verio. 2015. Response three varieties of soybean (Glycine $\max ($ L.) Merrill) alelopati against weed Ageratum conyzoides and Borreria alata. Skripsi. Faculty of Agriculture, Padjadjaran University. Bandung. (tidak dipublikasikan).

Donly, T., N. Setyowati, dan U. Nurjanah. 2009. Studi alelopati Wedelia trilobata, Ageratum conyzoides, Chromolaena odorata dan Mikania micrantha terhadap pertumbuhan dan hasil sawi. Skripsi. Fakultas Pertanian Universitas Bengkulu.(tidak dipublikasikan).

Dwijoseputro, D. 1992. Pengantar Fisiolo- gi Tumbuhan. PT. Gramedia Pustaka Utama. Jakarta. 232 hal.

Einheling, F.A. 1995. Mechanism of Action of Allelochemicals in Allelopathy. In Inderjit, K.M.M. Dakshini and F.A. Einhelling (Eds). Allelopathy: Organisms, Processes and Aplication. American Chemical Society, Washington D.C.

Eni, S. 2010. Pemanfaatan kulit jengkol (Pithecellobium jiringa) sebagai bioherbisida gulma dan biolarvasida. Persyaratan Lomba Pemilihan Mahasiswa Berprestasi. Fakultas Matematika Dan Ilmu Pengetahuan Alam. Universitas Negeri Medan.

Fery, J. dan P. Puspitorini, 2013. Efektifitas penggunaan pupuk kascing dan ekstrak teh terhadap pertumbuhan dan hasil tanaman sawi hijau (Brassica juncea L.). Grafting 1(3): 1-9.

Fuat, F. 2009. Budidaya caisim (Brassica juncea L.) menggunakan ekstrak teh dan pupuk kascing. Skripsi. Fakultas Pertanian Universitas Sebelas Maret Sukakarta. (tidak dipublikasikan).

Karina, I.K dan I.M Sukadana, 2000. Sayuran Organik. http:www.pustaka deptan.go.id/ agritek/bali0208.pdf. Diakses pada tanggal 10 Mei 2016.

Lakitan, B. 2004. Dasar-dasar Fisiologi Tumbuhan. PT. Raja Gravindo Persada. Jakarta. 206 hal.

Masriadi. 2014. Pengaruh herbisida ekstrak kulit buah jengkol terhadap pertumbuhan dan hasil tanaman jagung manis (Zea mays saccharata Sturt). Skripsi. Fakultas Pertanian, Universitas Taman Siswa, Padang. (tidak dipublikasikan).

Nie, C. 2007. Allelopathic potensial of $\mathrm{Wi}$ delia trilobata L. on rice. Acta Agro- 
146 Putriany Simanjuntak, Uswatun Nurjanah, Edhi Turmudi : Respon Sawi pada Berbagai Konsentrasi

nomica Sinica 30(9): 942-946.

Nurjannah, U. 2013. Kajian alelokimia kulit buah jengkol pada gulma padi sawah. Universitas Gajah Mada. Yogyakarta.

Nurjannah, U., E.Turmudi, dan Hasanudin. 2015. Efikasi alelokimia kulit buah jengkol segar pada perkecambahan Ludwigia Octovalvis (Jacq) revans. Prosiding Seminar Nasional XIX HIGI Himpunan Ilmu Gulma (editor : Prof. Dr. Ir. Denny Kurniadie, M.Sc, Dr. Uum Umiyanti, S.P., M.P.). Desember 2015.

Pabinru, A.M. 1979. Penelitian alelopati pada beberapa tanaman di tanah kering. Thesis Pasca Sarjana Institut Pertanian Bogor, Bogor. (Tidak dipublikasikan).

Rice, E.L. 1974. Allelopathy. Academic Press Inc. London.

Sodaeizaedah, H., M. Rafieiolhossaini, J. Havli'k, and P. Van Damme, 2009.
Allelopathic activity of different plant parts of Peganum harlama L. and identification of their growth inhibitors substances. Plant Growth Regul 59: 227 - 236.

Susanti. 2010. Pemanfaatan kulit jengkol (Pithecellobium jiringa) sebagai bioherbisida gulma dan biolarvasida Aedes aegepty. Lomba Pemilihan Mahasiswa Berprestasi Universitas Negeri Medan, Fakultas Matematika dan Ilmu Pengetahuan Alam, UNIMED. Medan.

Zuhri, S., Y. Delsi, dan Solfiyeni. 2010. Vigor padi (Oryza sativa) dengan pemberian beberapa konsentrasi ekstrak kulit jengkol (Pithecelobium jiringa (Jack) Prain ex King). Prosiding Seminar Biologi Departemen Biologi FMIPA Universitas Sumatera Utara (editor : Salomo Hutahean, Syafrudin Ilyas, Suci Rahayu dan Kaniwa Berliani). USU Press. Medan. P : 766-773. 11 Januari 2011. 